\title{
Sacral Agenesis
}

National Cancer Institute

\section{Source}

National Cancer Institute. Sacral Agenesis. NCI Thesaurus. Code C99054.

A rare cong enital abnormality characterized by partial or complete absence of the lower portion of the spine. 